https:/unars.ac.id/ojs/index.php/pgsdunars/index

\title{
PENINGKATAN HASIL BELAJAR KOGNITIF MELALUI MODEL PEMBELAJARAN KOOPERATIF TIPE NUMBERED HEAD TOGETHER (NHT) TEMA PERKALIAN DAN PEMBAGIAN PECAHAN
}

\author{
Muhammad Erfan', Nursina Sari², Nani Suarni ${ }^{3}$, Mohammad Archi Maulyda ${ }^{4}$, \\ Dyah Indras wati ${ }^{5}$ \\ 1,4,5 Program Studi Pendidikan Guru Sekolah Dasar, FKIP Universitas Mataram \\ ${ }^{2}$ Program Studi Pendidikan Guru Sekolah Dasar, FKIP Universitas Muhammadiyah Mataram \\ ${ }^{3}$ Guru Sekolah Dasar Negeri3 Batu Kumbung
}

email: muhammaderfan@unram.ac.id $\underline{\text { nursinasari@ummat.ac.id }}^{2}$ nanisuarni@,gmail.com $^{3}$ archimaulyda@unram.ac.id ${ }^{4}$ dyahindraswati@unram.ac.id ${ }^{5}$

\begin{abstract}
The theme of multiplication and division of fractions in mathematics learning is still difficult for students in grade IV SDN 3 Batu Kumbung. This is evidenced by the low achievement of students' cognitive learning outcomes on the theme of multiplication and division of fractions that are on average below the KKM. Therefore, this study aims to improve cognitive learning outcomes through variations in the learning model with the cooperative learning model Numbered Head Together (NHT) on the theme of multiplication and division of fractions. This research is a classroom action research conducted on grade $I V$ students of SDN 3 Batu Kumbung, amounting to 21 people with two cycles. Data obtained by test techniques and analysed through descriptive statistics. The results showed that from the first cycle there was only a slight increase, but after the fourth grade students were given instructions and reinforcement, cognitive learning outcomes on the multiplication and division fraction themes increased beyond the KKM value. The cycle is stopped after the average value of cognitive learning outcomes on the multiplication and division of fraction themes has been reached or exceeds the value of minimum completeness criteria.
\end{abstract}

Keywords: NHT, mathematics, elementary school, fractional operations

\begin{abstract}
ABSTRAK
Tema perkalian dan pembagian pecahan pada pembelajaran matematika masih menjadi hal yang sulit bagi peserta didik di kelas IV SDN 3 Batu Kumbung. Hal ini dibuktikan dengan rendahnya capaian hasil belajar kognitif peserta didik pada tema perkalian dan pembagian pecahan yang rata-rata dibawah KKM. Oleh karena itu, penelitian ini bertujuan untuk meningkatkan hasil belajar kognitif melalui variasi model pembelajaran dengan model pembelajaran kooperatif tipe Numbered Head Together (NHT) pada tema perkalian dan pembagian pecahan. Penelitian ini merupakan penelitian tindakan kelas yang dilakukan pada peserta didik kelas IV SDN 3 Batu Kumbung yang berjumlah 21 orang dengan dua siklus. Data diperoleh dengan teknik tes dan dianalisis melalui statistik deskriptif. Hasil penelitian menunjukkan bahwa dari siklus pertama hanya terdapat sedikit peningkatan, namun setelah para peserta didik kelas IV diberikan petunjuk dan penguatan, hasil belajar kognitif pada tema perkalian dan pembagian pecahan meningkat melebihi nilai KKM. Siklus dihentikan setelah nilai rata-rata hasil belajar kognitif pada tema perkalian dan pembagian pecahan telah tercapai atau melebihi nilai kriteria ketuntasan minimal.
\end{abstract}

Kata Kunci: NHT, matematika, sekolah dasar, operasi pecahan 


\section{PENDAHULUAN}

Salah satu dari delapan keterampilan mengajar yang wajib dikuasai oleh pendidik adalah keterampilan merancang skenario dan proses pembelajaran yang bervariasi (Uniarsi, 2014). Keterampilan mengadakan variasi merupakan keterampilan pendidik dalam menggunakan berbagai macam kemampuan untuk mewujudkan tujuan belajar peserta didik sekaligus mengatasi kebosanan serta menimbulkan minat, gairah, dan aktivitas belajar yang efektif (Yahya, 2014). Karena faktor motivasi belajar peserta didik merupakan faktor yang penting dalam keberhasilan proses belajar mengajar (Muhammad, 2016), maka keterampilan pendidik dalam mengadakan variasi dalam proses pembelajaran menjadi tidak kalah penting peranannya.

Variasi dalam proses pembelajaran yang dapat dilakukan oleh pendidik tidak hanya berupa penggunaan media pembelajaran yang baru tetapi juga dapat dilakukan dengan menerapkan berbagai model pembelajaran yang dapat melibatkan tidak hanya keaktifan peserta didik tetapi juga kerja sama antar peserta didik ketika proses pembelajaran di kelas berlangsung. Proses kerja sama antar peserta didik maupun antara pendidik dan peserta didik dalam berdiskusi mengenai suatu materi pembelajaran dapat dikategorikan ke dalam pembelajaran kooperatif (Suparmi, 2012).

Salah satu tipe model pembelajaran kooperatif adalah numbered head together (NHT) yang terdiri atas empat tahap yang digunakan untuk mereview fakta-fakta dan informasi dasar yang berfungsi untuk mengatur interaksi peserta didik (Alie, 2013). Keempat tahap tersebut di antaranya adalah penomoran, pengajuan pertanyaan, berpikir bersama, serta pemberian jawaban (Siregar, 2012). Melalui pembelajaran kooperatif tipe NHT, seluruh peserta didik dituntut aktif memecahkan suatu masalah bersama-sama sehingga berbagai pertanyaan akan dirasa ringan karena dalam proses menjawabnya dilakukan secara bersama-sama.

Berdasarkan hasil observasi dan wawancara yang dilakukan di SDN 3 Batu Kumbung diperoleh hasil bahwa peserta didik mengalami kesulitan memahami konsep pembagian dan perkalian pecahan dalam muatan materi pelajaran matematika. Hal ini dikarenakan penggunaan model pembelajaran yang kurang bervariasi menyebabkan pembelajaran kurang efektif dan membosankan. Peserta didik juga terlihat kurang aktif, dan terlihat sibuk sendiri hal tersebut dikarenakan oleh guru lebih cenderung hanya menggunakan metode ceramah, dan tanya jawab tanpa adanya kegiatan yang melibatkan peserta didik baik untuk menyampaikan pendapatnya pada pendidik maupun untuk berinteraksi dengan anggota peserta didik lainnya melalui kegiatan kelompok diskusi. Terlebih matematika sebagai konsep ilmu tentang bilangan, hubungan antara suatu bilangan, dan suatu prosedur operasional yang digunakan dalam hal penyelesaian masalah mengenai bilangan, serta hubungannya dengan suatu angka dan simbol-simbol menjadikan peserta didik menjadi lebih sulit untuk memahaminya. 
Permasalahan tersebut, tentunya berdampak pada hasil belajar yang terlihat pada nilai KKM peserta didik. Dari 21 orang peserta didik, terdapat sebanyak 11 orang peserta didik yang mendapatkan nilai kurang dari KKM dan 10 orang peserta didik sudah memenuhi nilai KKM. Berdasarkan permasalahan tersebut, konsep pembagian dan perkalian pecahan perlu disajikan dalam suasana pembelajaran yang aktif dan menyenangkan, sehingga dapat menarik minat dan mengembangkan potensi peserta didik. Oleh karena itu bertujuan untuk meningkatkan hasil belajar kognitif peserta didik pada tema perkalian dan pembagian bilangan pecahan dengan model pembelajaran kooperatif tipe NHT. Selain itu penelitian ini juga berupaya untuk memberi masukan terhadap berbagai upaya pendidik dalam mengatasi berbagai masalah dalam proses pembelajaran dan memperluas wawasan pendidik dalam membelajarkan matematika di sekolah dasar khususnya di SDN 3 Batu Kumbung.

\section{METODE}

Penelitian ini merupakan penelitian tindakan kelas (classroom action research). Dalam kegiatan penelitian ini, yang melakukan tindakan adalah guru kelas dan otomatis guru terlibat secara langsung dalam proses penelitian dari awal. Penelitian ini di lakukan di kelas IV (empat) SDN 3 Batu Kumbung dengan subyek peserta didik sebanyak 21 orang. Teknik pengumpulan data yang digunakan dalam penelitian ini adalah teknik tes dengan 20 butir soal kemampuan mengali dan membagi bilangan pecahan.

Proses penelitian dilaksanakan secara siklik dengan memperhatikan beberapa tahap penelitian tindakan di antaranya adalah plan, implementation, monitoring, serta implementation sebagaimana tahapan yang diperkenalkan oleh Kemmis and McTaggart (1988). Pada tahapan penelitian tindakan, bagian implementation sudah termasuk dalam bagian Action/Observation dan untuk bagian monitoring and reflection sudah termasuk dalam bagian Reflection. 


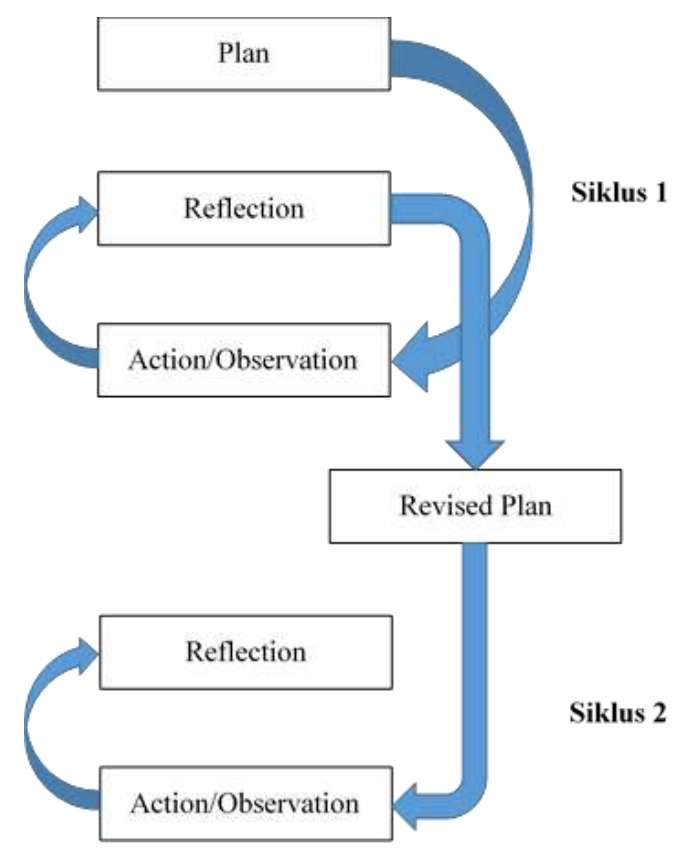

Gambar 1. Alur Penelitian Tindakan Kelas (Kemmis \& McTaggart, 1988)

Setiap akhir siklus, peneliti melakukan refleksi untuk perbaikan pada siklus selanjutnya. Dalam kegiatan refleksi, peneliti berusaha memahami dan mengevaluasi proses, masalah, persoalan, dan kendala nyata dalam tindakan yang telah dilakukan. Selanjutnya, untuk menghindari kendala yang sama, peneliti melakukan langkah-langkah antisipasi berdasarkan hasil analisis reflektif yang telah di lakukan.

Data dalam penelitian ini dianalisis dengan analisis deskriptif dengan jenis data yang diperoleh adalah data kuantitatif yang ditampilkan dan dibahas dalam bentuk tabel, gambar, serta ukuran-ukuran statistik deskriptif seperti rata-rata, nilai minimum maksimum, deviasi standar, serta untuk mengetahui seberapa tinggi peningkatan hasil belajar kognitif peserta didik pada tema perkalian dan pembagian pecahan digunakan uji gain ternormalisasi (N-Gain). Tinggi rendahnya gain score ternormalisasi dikategorikan dalam tiga kategori (tinggi, sedang, rendah) yang disajikan pada Tabel 1 (Cheng, Thacker, Cardenas, \& Crouch, 2004)(Erfan, Maulyda, Gunawan, Sari, \& Ratu, 2020).

Tabel 1. Kriteria Skor/Nilai Gain Ternormalisasi (Hake, 1998)

\begin{tabular}{cc}
\hline Kriteria Peningkatan Nilai Gain & Nilai Gain Ternormalisasi \\
\hline Gain tinggi & $\mathrm{g} \geq 0,7$ \\
Gain sedang & $0,3 \leq \mathrm{g}<0,7$ \\
Gain rendah & $\mathrm{g}<0,3$ \\
\hline
\end{tabular}




\section{PEMBAHASAN}

Pada tahapan perencanaan tindakan di siklus I, guru merencanakan dan menyusun rancangan tindakan yang akan dilaksanakan sesuai dengan temuan masalah dan gagasan awal. Pada tahap ini guru mengembangkan sendiri rencana pelaksanaan pembelajaran (RPP) dan lembar kerja peserta didik serta merancang soal pretest untuk mengetahui seberapa jauh pemahaman awal peserta didik terhadap konsep perkalian dan pembagian bilangan pecahan.

Pembuatan lembar kerja peserta didik (LKPD) disusun berdasarkan Kompetensi Inti dan Kompetensi Dasar yang ingin dicapai satuan pendidikan sesuai dengan gugus sekolah dasar serta menyesuaikan dengan materi yang diajarkan yaitu operasi perkalian dan pembagian pada bilangan pecahan. Selain itu RPP yang dibuat juga ditambahkan dengan sintaks jalannya pembelajaran penerapan model pembelajaran kooperatif tipe numbered head together (NHT).

\section{Hasil tahap action/observation siklus I}

Tahap action/observation pada siklus I merupakan kegiatan tindakan guru di kelas yang menggunakan model pembelajaran kooperatif tipe NHT dalam pembelajaran tema perkalian dan pembagian bilangan pecahan. Kegiatan pembelajaran pada tahap action/observation siklus I dilangsungkan selama 2 kali pertemuan dengan pertemuan pertama kegiatan pembelajaran membahas tentang perkalian berbagai macam jenis pecahan serta pendidik menjelaskan bagaimana bentuk pengoperasian perkalian pada berbagai macam bentuk pecahan. Pertemuan kedua, kegiatan pembelajaran membahas tentang operasi pembagian pada bilangan pecahan. Selain itu berbagai teknik yang harus dikuasai peserta didik dalam operasi pembagian pada bilangan pecahan juga diajarkan melalui model pembelajaran kooperatif tipe NHT.

Kegiatan pembelajaran pada siklus I baik pada pertemuan pertama maupun pada pertemuan kedua diawali dengan kegiatan apersepsi dan pemberian motivasi bagi peserta didik. Guru menjelaskan mengenai kegiatan pembelajaran yang akan dilaksanakan, mengenai apa saja yang akan dipelajari serta capaian hasil belajar apa saja yang diharapkan dapat dicapai oleh peserta didik. Pada tahap ini guru juga menjelaskan mengenai teknis pelaksanaan pembelajaran dengan model pembelajaran kooperatif tipe NHT kepada peserta didik yang telah dibagi menjadi 4 kelompok. Setiap kelompok rata-rata terdiri atas 5 orang peserta didik (ada salah satu kelompok 6 orang peserta didik) dan masing-masing kelompok mendapatkan nomor tanda 1 - 4 . Selanjutnya pendidik memberikan soal melalui lembar kerja peserta didik dengan setiap kelompok mendapat jenis soal yang sama, setelah peserta didik mendiskusikan soal yang ada di LKPD dengan kelompoknya masing-masing, pendidik menunjuk secara acak perkelompok maju ke depan kelas untuk mendapatkan jawaban yang berbeda-beda. Setelah setiap perwakilan kelompok maju mengerjakan di depan kelas, pendidik menjelaskan dan membahas jawaban dari 
kelompok yang berbeda-beda dengan lebih menekankan pada persamaan dan perbedaan jawaban masing-masing kelompok.

Setelah semua kegiatan pembelajaran pada tema perkalian dan pembagian bilangan pecahan, di akhir kegiatan dilakukan post-test untuk mengetahui apakah terdapat peningkatan hasil belajar kognitif peserta didik. Post-test dilakukan sebagai cara untuk mengetahui adanya umpan balik yang diperlukan sekiranya di dalam proses pembelajaran pada siklus I masih terdapat kekurangan dan perlu penyempurnaan dan perhatian khusus.

\section{Hasil tahap reflection siklus I}

Setelah kegiatan pada tahap action/observation siklus I dilaksanakan, terdapat beberapa catatan penting berkaitan jalannya proses pembelajaran dengan model pembelajaran kooperatif tipe NHT pada tema perkalian dan pembagian pada bilangan pecahan.

Pada saat peserta didik berdiskusi, pengelolaan kelas dimana pada waktu pembagian kelompok dan penyusunan formasi tempat duduk peserta didik cenderung lebih sulit untuk fokus sehingga pelaksanaan diskusi banyak peserta didik yang bercanda, dan akibatnya pelaksanaan diskusi menjadi tertunda. Selain itu, ketika masing-masing perwakilan kelompok ditunjuk untuk maju ke depan kelas untuk menjawab dan menjelaskan pertanyaan dan jawabannya, peserta didik yang ada di masing-masing kelompok masih ada yang saling tunjuk. Setelah beberapa anak yang ada di masing-masing kelompok ditanya mengapa saling tunjuk, beberapa peserta didik menjawab bahwa beberapa masih takut menjawab karena takut menjawab salah.

Akhir kegiatan tahap action/observation siklus I dilakukan tahap post-test untuk melihat sejauh mana peningkatan capaian hasil belajar kognitif pada siklus I. Hasil statistik deskriptif yang menjadi acuan perencanaan kegiatan pada siklus selanjutnya ditunjukkan pada Tabel 2.

Tabel 2. Statistik deskriptif capaian hasil belajar siklus I

\begin{tabular}{cccc}
\hline Statistik Deskriptif & Pre-test & Post-test $\mathbf{1}$ & Gain Post-test I \\
\hline Nilai Maksimum & 65,00 & 75,00 & \\
Nilai Minimum & 40,00 & 50,00 & \\
Rerata (mean) & 51,43 & 62,14 & 0,22 \\
Median & 50,00 & 60,00 & (rendah) \\
Modus & 55,00 & 70,00 & \\
Std.deviasi & 7,61 & 7,51 & \\
\hline
\end{tabular}

Berdasarkan Tabel 2, diketahui bahwa peningkatan nilai rata-rata kemampuan peserta didik dalam operasi perkalian dan pembagian pada bilangan pecahan masih tergolong rendah. Hal ini dapat dilihat dari nilai Gain pada post-test I yang hanya 0,22 dengan kategori gain rendah. Dari 
nilai rata-rata dapat diketahui bahwa baik nilai pre-test maupun nilai post-test sama-sama berada di bawah nilai $\mathrm{KKM}(80)$.

\section{Hasil tahap action/observation siklus II}

Hasil refleksi pada siklus I menjadi umpan balik utama dalam pelaksanaan proses pembelajaran yang dilakukan pada siklus II. Proses pembelajaran dengan model kooperatif tipe NHT pada siklus II lebih kurang sama dengan kegiatan pembelajaran pada siklus I namun terdapat beberapa hal yang ditambahkan dan beberapa hal yang perlu diberi penguatan.

Hal yang ditambahkan dan diperbaiki pada kegiatan pembelajaran di siklus II adalah pada proses pembagian kelompok yang sudah dibagi secara tetap, jadi tidak ada lagi peserta didik yang merasa kebingungan mencari kelompoknya, setiap soal dibagi rata ke masing-masing kelompok dengan bagian-bagian soal yang terpecah sesuai dengan jumlah peserta didik yang ada pada masing-masing kelompok. Setiap peserta didik yang ada di masing-masing kelompok mendapat giliran yang sama untuk bertanya maupun menjawab soal-soal yang memang dapat bagiannya. Selain itu, pendidik juga memperhatikan kedekatan pertemanan dari masing-masing kelompok. Kelompok yang anggotanya memang sudah berteman dekat dikelompokkan menjadi satu kelompok, begitu pula dengan kelompok lain yang mendapat perlakuan sama. Pendidik selain mengatur jalannya proses pembelajaran dengan saksama, juga dilakukan penguatan semacam dorongan semangat bagi peserta didik yang mengerjakan soal di depan kelas maupun bagi peserta didik yang berani menjawab soal yang berkaitan dengan operasi hitung perkalian maupun pembagian pada bilangan pecahan.

\section{Hasil tahap reflection siklus II}

Pada kegiatan tahap action/observation siklus II, sebagian besar peserta didik telah terbiasa dengan model pembelajaran kooperatif tipe NHT. Pada kegiatan inti siklus II ini pun pendidik lebih mudah dalam penataan dan pengelolaan kelas sehingga suasana pembelajaran menjadi lebih kondusif dan peserta didik menjadi lebih aktif.

Akhir kegiatan tahap action/observation siklus II juga dilakukan tahap post-test untuk melihat sejauh mana peningkatan capaian hasil belajar kognitif pada siklus II. Hasil statistik deskriptif yang menjadi acuan perencanaan kegiatan pada siklus selanjutnya ditunjukkan pada Tabel 3. 
Tabel 3. Statistik deskriptif capaian hasil belajar siklus II

\begin{tabular}{cccc}
\hline Statistik Deskriptif & $\begin{array}{c}\text { Post-test I } \\
\text { (Pre-test II) }\end{array}$ & Post-test II & Gain Post-test II \\
\hline Nilai Maksimum & 75,00 & 95,00 & \\
Nilai Minimum & 50,00 & 70,00 & \\
Rerata (mean) & 62,14 & 80,48 & 0,48 \\
Median & 60,00 & 80,00 & (sedang) \\
Modus & 70,00 & 80,00 & \\
Std.deviasi & 7,51 & 7,23 & \\
\hline
\end{tabular}

Berdasarkan Tabel 3 dapat diketahui bahwa terjadi peningkatan nilai rata-rata hasil belajar yang cukup signifikan. Nilai Gain yang diperoleh jika dibandingkan dengan hasil belajar pada post-test di siklus I diperoleh nilai Gain 0,48 dengan kriteria Gain sedang. Di akhir siklus II dimana diperoleh nilai rata-rata hasil belajar kognitif yang sedikit melebihi nilai kriteria ketuntasan minimal (KKM) yaitu 80,48 mengindikasikan kegiatan tindakan diakhiri cukup di siklus II.

Tindakan-tindakan untuk meningkatkan hasil belajar kognitif peserta didik dalam pembelajaran matematika di sekolah dasar pada tema operasi perkalian dan pembagian pada bilangan pecahan dilakukan sebanyak dua siklus. Siklus tindakan dihentikan setelah tujuan penelitian tindakan telah tercapai atau rata-rata hasil belajar kognitif peserta didik telah mencapai atau melebihi nilai kriteria ketuntasan minimal (KKM).

Diawali kegiatan kendala yang ditemukan di antaranya adalah belum terbiasanya peserta didik dengan model pembelajaran kooperatif tipe NHT karena selama ini di SDN 3 Batu Kumbung khususnya di kelas IV pendidik lebih menekankan membelajarkan matematika dengan metode konvensional ceramah. Ketika diterapkan model pembelajaran kooperatif tipe NHT untuk yang pertama kali jadi wajar peserta didik memerlukan beberapa waktu untuk penyesuaian. Hal ini disiasati oleh pendidik dengan mengupayakan manajemen kelas secara teratur tetapi tanpa menghilangkan kehangatan hubungan antara pendidik dan peserta didik ketika proses pembelajaran berlangsung. Selain itu pada siklus kedua pendidik menjadi lebih tegas terhadap siswa yang main-main ketika proses pembelajaran berlangsung.

Meningkatnya nilai hasil belajar peserta didik di akhir siklus II tidak dapat lepas dari pengelolaan kelas yang baik oleh pendidik di kegiatan utama siklus II. Pengelolaan kelas yang baik merupakan salah satu kunci peserta didik menjadi lebih fokus dengan materi pembelajaran yang sedang dibahas, porsi keikutsertaan peserta didik dalam berpikir semakin lama sehingga pada akhirnya hasil belajar kognitif peserta didik dapat meningkat sesuai dengan yang 
diharapkan.

Meningkatnya hasil belajar kognitif peserta didik salah satunya juga dipengaruhi oleh adanya penguatan (reinforcement) yang dilakukan pendidik kepada peserta didik selama kegiatan utama pada siklus II berlangsung. Penguatan-penguatan ini tidak hanya berupa penguatan dalam bentuk verbal dalam bentuk pujian dan pemberian semangat bagi para peserta didik yang berani mengemukakan pendapatnya dan berani mengerjakan soal-soal di depan kelas tetapi juga penguatan dalam bentuk tindakan pendidik yang memberikan penghargaan bagi peserta didik yang tidak hanya menjawab benar tetapi juga bagi peserta didik yang sudah mau terlibat aktif bertanya maupun menjawab hal yang diajukan oleh pendidik selama kegiatan pembelajaran berlangsung. Hasil penelitian yang telah dilakukan oleh Wiegand \& Geller (2005), Supriyo (2016), Zebua (2017), dan Rumfola (2017) mendukung hasil penelitian tindakan ini di mana pemberian penguatan positif tidak hanya memberikan dampak yang baik terhadap proses belajar mengajar tetapi juga meningkatkan capaian hasil belajar peserta didik dalam suatu kegiatan proses pembelajaran.

Penggunaan model pembelajaran kooperatif tipe NHT tidak hanya melibatkan aktif peserta didik dalam segala kegiatan pembelajaran tetapi juga terbukti dapat meningkatkan capaian hasil belajar kognitif peserta didik. Meningkatnya hasil belajar peserta didik yang dibelajarkan dengan model kooperatif tipe NHT juga sejalan dengan penelitian yang telah dilakukan oleh Sutipnyo \& Mosik (2018) dan Destiningsih, Usodo, \& Mardiyana (2013) dimana penerapan Numbered Head Together (NHT) dalam proses pembelajaran selain dapat meningkatkan hasil belajar dan keaktifan peserta didik di kelas, juga dapat membuat proses pembelajaran menjadi lebih menyenangkan.

\section{KESIMPULAN}

Berdasarkan keseluruhan kegiatan penelitian tindakan kelas sebanyak dua siklus dengan menggunakan model pembelajaran kooperatif tipe NHT pada peserta didik kelas IV SDN 3 Batu Kumbung dapat disimpulkan bahwa penggunaan model pembelajaran kooperatif tipe NHT dapat meningkatkan hasil belajar kognitif peserta didik pada tema operasi perkalian dan pembagian pada bilangan pecahan. Hal ini dapat di lihat dari nilai Gain pada siklus I $(0,22)$ yang berada pada kategori rendah (belum signifikan) dan nilai Gain pada siklus II $(0,48)$ yang berada pada kategori sedang (cukup signifikan).

\section{DAFTAR PUSTAKA}

Alie, N. H. (2013). Penggunaan Model Pembelajaran Kooperatif Tipe NHT Untuk Meningkatkan Hasil Belajar Siswa Kelas X2 SMA Neg. 3 Gorontalo Pada Materi Jarak 
Pada Bangun Ruang. JURNAL ENTROPI: Inovasi Penelitian, Pendidikan Dan Pembelajaran Sains, 7(1), 583-592.

Cheng, K. K., Thacker, B. A., Cardenas, R. L., \& Crouch, C. (2004). Using an online homework system enhances students' learning of physics concepts in an introductory physics course. American Journal of Physics, 72(11), 1447-1453. https://doi.org/10.1119/1.1768555

Destiningsih, N., Usodo, \& Mardiyana, M. (2013). The Effectiveness of Cooperative Learning Model Numbered Head Together (NHT) and Make a Match on Student Mathematics Learning Achievement in terms of Student Social Skill in Class X Vocation School in Wonogiri Regency Year 2012/2013. Journal of Scientific Mathematics Education, 2(1), $1-12$.

Erfan, M., Maulyda, M. A., Gunawan, G., Sari, N., \& Ratu, T. (2020). Enhancing Students Ability in Analyzing Image Formation on Lens and Mirror Using Ray Optics. Journal of Physics: Conference Series, 1471, 012061. https://doi.org/10.1088/17426596/1471/1/012061

Hake, R. R. (1998). Interactive-engagement versus traditional methods: A six-thousand-student survey of mechanics test data for introductory physics courses. American Journal of Physics, 66(1), 64-74. https://doi.org/10.1119/1.18809

Kemmis, S., \& McTaggart, R. (1988). The Action Research Reader (Third). Victoria: Deakin University Press.

Muhammad, M. (2016). Pengaruh motivasi dalam pembelajaran. Lantanida Journal, 4(2), 86-97.

Rumfola, L. (2017). Positive Reinforcement $P$ ositively Helps Students in the Classroom. Brockport.

Siregar, F. A. (2012). Pengaruh model kooperatif tipe nht terhadap hasil belajar siswa kelas VIII SMP Negeri 18 Medan. Jurnal Pendidikan Fisika, 1(1), 33-38.

Suparmi. (2012). Pembelajaran kooperatif dalam pendidikan multikultural. Jurnal Pembangunan Pendidikan: Fondasi Dan Aplikasi, 1(1), 108-118.

Supriyo. (2016). The Implementation of Practice Generalization Reinforcement (PGR) Learning Strategy to Improve English Grammar Learning Outcomes in Junior High School. IOSR Journal of Research \& Method in Education, 6(6), 50-54. https://doi.org/10.9790/73880606045054

Sutipnyo, B., \& Mosik, M. (2018). The Use of Numbered Heads Together (NHT) Learning Model with Science, Environment, Technology, Society (SETS) Approach to Improve Student Learning Motivation of Senior High School. Jurnal Pendidikan Fisika Indonesia, 14(1), 26-31. https//doi.org/10.15294/jpfi.v14i1.13929

Uniarsi, M. (2014). Penerapan keterampilan guru mengadakan variasi pada pembelajaran matematika terhadap hasil belajar siswa kelas IV. Jurnal Pendidikan Dan Pembelajaran Khatulistiwa, 3(6), 1-11.

Wiegand, D. M., \& Geller, E. S. (2005). Connecting Positive Psychology and Organizational Behavior Management. Journal of Organizational Behavior Management, 24(1-2), 325. https://doi.org/10.1300/J075v24n01 02

Yahya, M. D. (2014). Variasi metode mengajar guru dalam menumbuhkan minat belajar siswa pada mata pelajaran akidah akhlak di MTs Ni'matul Aziz Kabupaten Barito Kuala. Tarbiyah Islamiyah: Jurnal Ilmiah Pendidikan Agama Islam, 4(1), 1-35. https://oi.org/10.18592/jt ipai.v4i1.1838 
Zebua, K. A. D. P. (2017). The use of verbal reinforcement to motivate the 11th grade students of SMA Budya Wacana Yogyakarta to Speak English. Universitas Sanata Dharma. 